M.I. Baranov

\title{
AN ANTHOLOGY OF THE DISTINGUISHED ACHIEVEMENTS IN SCIENCE AND TECHNIQUE. PART 32: ALTERNATIVE ENERGY: STATE AND PROSPECTS OF DEVELOPMENT
}

\begin{abstract}
Purpose. Implementation of brief analytical review of the state and prospect of development in the modern world of alternative energy, including wind energy, sun energy, geothermal energy, biogas energy, flood-tide water energy, hydrogen energy and small water energy. Methodology. Scientific methods of collection, analysis and analytical treatment of scientific and technical information in area of the present state of world energy and ways of its further development. Results. A brief scientific and technical review is resulted about the state and prospects of world development of basic types of alternative energy. It is shown that, in spite of comparatively small stake (to $10 \%$ of this untraditional energy in general world balance of making of electric power, world association taking into account the necessary changing in the nearest 50 years of present oil-gas "foundation" of energy on other with large raw material, potential and ecological possibilities are forced to invest large financial means in development of the indicated directions of alternative energy. Originality. First on the basis of materials of separate magazine publications, scientific monographs and internetreports on power problem the brief analytical review of the state and prospects of world development of basic types of alternative energy is executed. Practical value. Deepening and spread of the scientific and technical learnings in area of functioning and ways of development of modern energy. Scientific popularization of arising up before society claimed tasks from global and important for all of humanity of power problem. References 30, figures 28 .
\end{abstract}

Key words: alternative energy, state and prospects of world development, review.

Приведен краткий научно-аналитический обзор о состоянии и перспективах мирового развития альтернативной энергетики, включающей ветроэнергетику, солнечную энергетику, геотермальную энергетику, биогазовую энергетику, приливную гидроэнергетику, водородную энергетику и малую гидроэнергетику. Библ. 30, рис. 28.

Ключевые слова: альтернативная энергетика, состояние и перспективы мирового развития, обзор.

Introduction. Energy, as we know, is that one of the main industrial sectors of the economy of any country in the world, in terms of development and the potential for that in a society is judged on the economic strength (power) of the country. Despite the continued leadership is currently in the global production of electric and thermal energy of its traditional high-power sources such as thermal, nuclear and hydroelectric power plants in recent years in the industrialized countries of the world their «momentum» is gaining alternative energy based on renewable energy sources of relatively small power [1] These promising renewable energy sources should be classified based primarily on the use of [1-8]: wind energy, solar energy, heat of the Earth's core, biogas energy from waste, the potential energy of the water with the installed capacity of hydroelectric power plants (HPP) to (5-30) MW and energy from the use of hydrogen. Alternative energy, unlike traditional energy has almost unlimited source of raw materials and the potential for humanity. In addition, its practical use does not lead to negative environmental consequences for the nature around us. Given the urgency and the importance of energy issues for humanity, undeniable scientific and technical interest is the analytical summary of the latest achievements of scientists and experts around the world in addressing the urgent applications in the field of alternative energy.

Wind power. This type of alternative energy has become today one of the major scientific and technical «locomotives» in the promotion of renewable energy in the global energy market [2]. Wind power is that alternative energy industry, which specializes in the transformation of the kinetic energy of air masses moving in the lower layers of the Earth's atmosphere, in the electrical, mechanical, thermal, or other form of energy [2]. Wind energy is currently booming worldwide technical indus- try. So, in 2014 the amount of electrical energy that is produced by all wind turbines of the world amounted to $706 \mathrm{TW}$-hour (about $3 \%$ of the produced electricity humanity annual volume) [2]. In 2014, 85 countries used wind energy on a commercial basis. It should be noted that some countries especially intensively develop wind power. For example, Denmark in 2014 with the help of wind turbines (if $4845 \mathrm{MW}$ installed capacity) worked out to $39 \%$ of its annual volume of electricity production [2]. According to the European Wind Energy Association Germany in 2005 it had an installed capacity of wind turbines (windmills) in the amount of 18428 MW. In 2014, this installed capacity of wind turbines in Germany was already $34250 \mathrm{MW}$ [2]. As for Ukraine, then in 2005 the installed capacity of its wind turbine was $77 \mathrm{MW}$, and in 2014 - 498 MW [2]. For comparison, the Russian Federation (RF) has an installed capacity of its wind turbines of $14 \mathrm{MW}$ in 2005, and in 2009 - $18 \mathrm{MW}$ [2]. We mention the fact that in 2010 up to $44 \%$ of all wind power plants constructed in the world were concentrated in Europe, in Asia - $31 \%$, and in North America - $22 \%$ (the remaining $3 \%$ were all other continental part of the globe) [2]. According to statistics from the World Wind Energy Council the total installed capacity of wind power plants on the planet at the beginning of 2011 was about $238 \mathrm{GW}$ (the end of 2011 it increased by about $25 \%$ ) [2]. The development of wind energy on the planet in the 21 st century is the exponential growth rate. And so that every three years, the total installed capacity of wind power plants of the world doubled [9]. On the «face» of scientific, technical and commercial interests of society in the development and implementation in practice of wind power.

1.1. Types and design of wind turbines. Wind power and wind turbines used in it are, in fact, the techni- 
cal embodiment of a relatively new power generation technology. The main directions of development of modern wind power is autonomous, or «small» wind energy, based on the use of single wind turbine, and a centralized or «big» wind power, which is based on the use of wind power plants (WPP) [9]. The position of the rotor axis wind turbines are divided into horizontal-axis and vertical-axis [9]. Fig. 1 shows the appearance of the «farm» of modern horizontal-axis wind turbine installed capacity of up to $250 \mathrm{~kW}$, erected under field conditions in the coastal zone of the Russian Federation west [10]. Note that in the Russian Federation is the largest windfarm station «Zelenograd» installed capacity of 5.1 MW (Kaliningrad region), Consisting of 21 wind turbines of the Danish company «SEAS Energi Service A.S.» [2]. Fig. 2 schematically shows the arrangement of modern wind turbines horizontal axis performance, as shown in Fig. 3 a general view of a modern wind turbine vertical axis performance [11].

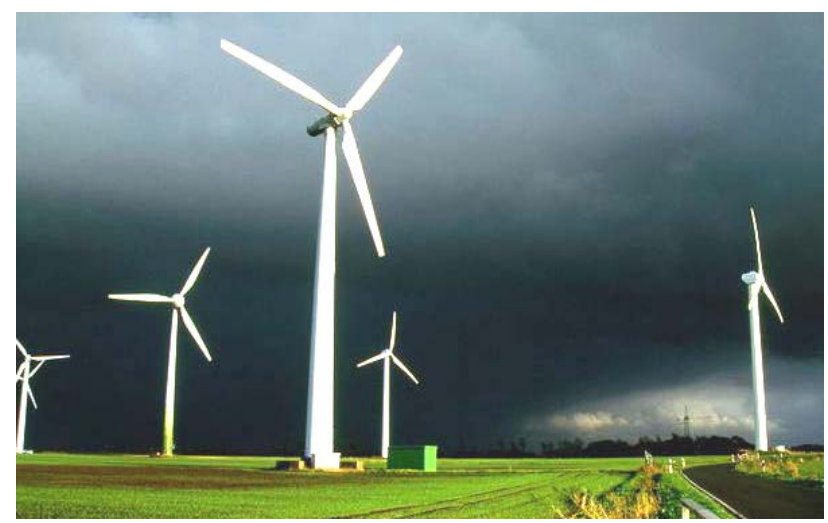

Fig. 1. General view of modern horizontal-axis three-bladed wind turbines installed, located on the flat coastal area up to $250 \mathrm{~kW}$ [10]

From the data (Fig. 2) it is shown that the main components of the wind turbine of this type is the actual wind turbine (turbine) and tower on which this wind turbine is located. Wind turbine contains a complex of structures and mechanisms.

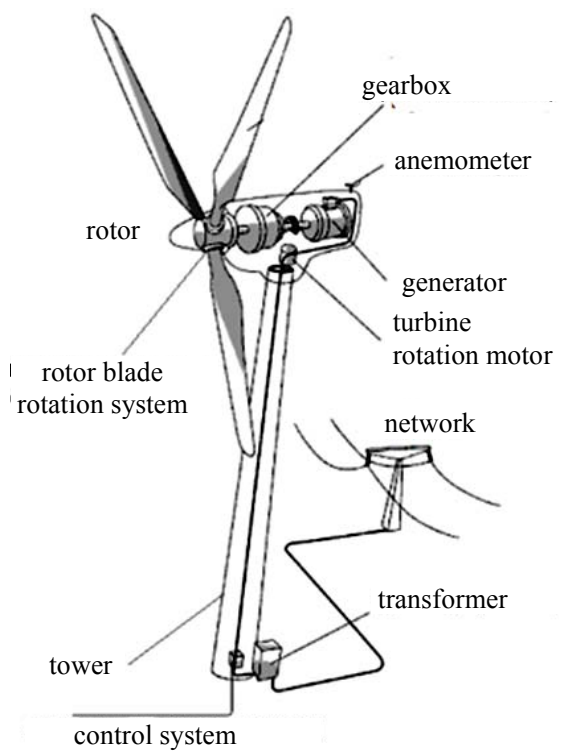

Fig. 2. A schematic design of the modern WPP $[9,10]$
Shown in Fig. 2 components and machinery of wind turbines required for its effective work in industrial production of electricity from wind energy and its subsequent transfer to the grid. Turbine of the WPP consists of the rotor and housing in which there are (see Fig. 2): anemometer; gearbox; generator; frequency converter; pitch system and yaw motor and yaw system; cooling system; control system and safety system $[9,10]$. Transformer can be placed directly near the foot of the tower of the WPP.

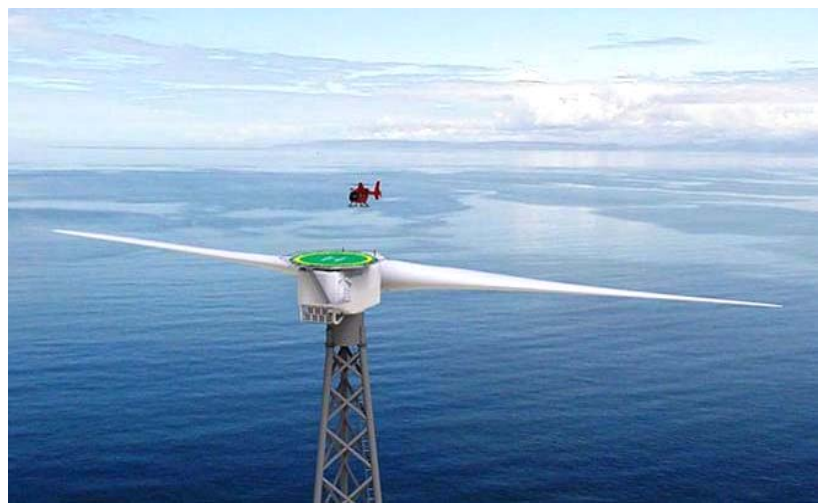

Fig. 3. General view of the Scottish vertical-axis wind turbines a twin sea-based with a helipad in the area of wind turbine capacity of up to $6000 \mathrm{~kW}$ [11]

Fig. 4-6 in an enlarged view show a giant turbine blades and modern three-blade horizontal axis wind turbine installed capacity of up to $1500 \mathrm{~kW}$ at holding them costly repair work $[9,11]$.

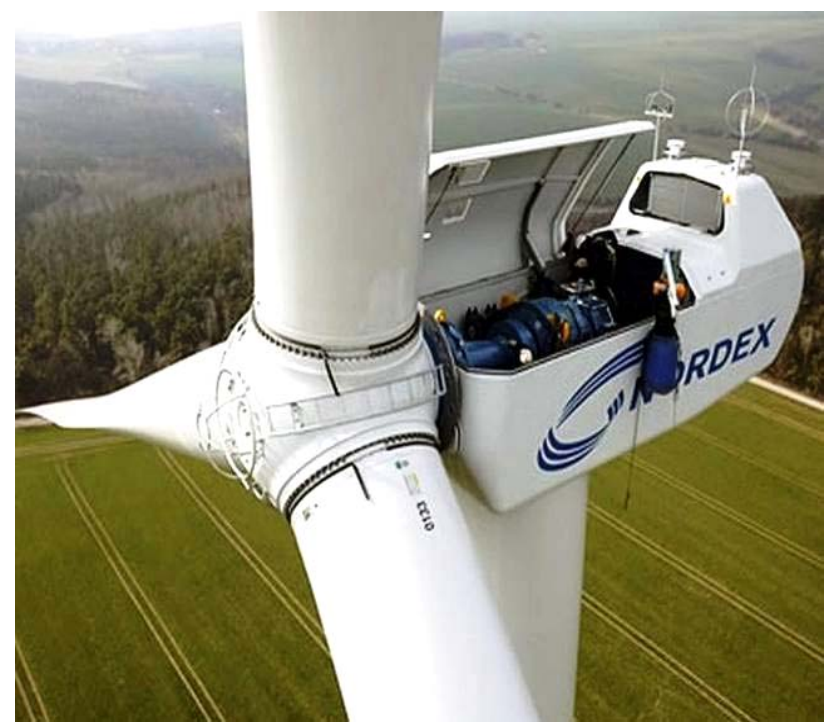

Fig. 4. The enlarged view of the turbine of modern horizontalaxis three-bladed wind turbines NORDEX marks the installed capacity of up to $1500 \mathrm{~kW}$ land-based during its maintenance at a height of about $70 \mathrm{~m} \mathrm{[11]}$ 


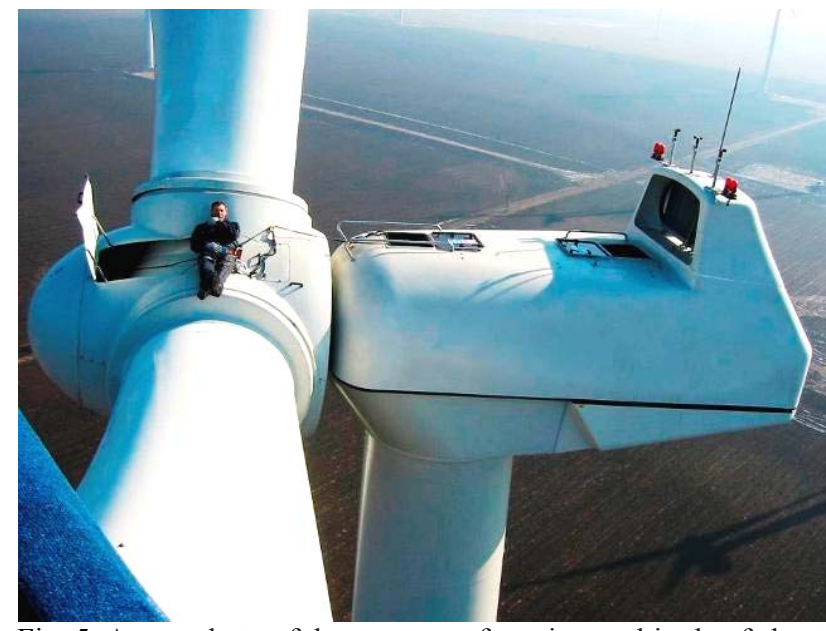

Fig. 5. A rare photo of the moment of service at altitude of about 70 meters and the turbine rotor blades of modern land-based horizontal-axis three-bladed wind turbine installed capacity of up to $1500 \mathrm{~kW}$ [11]

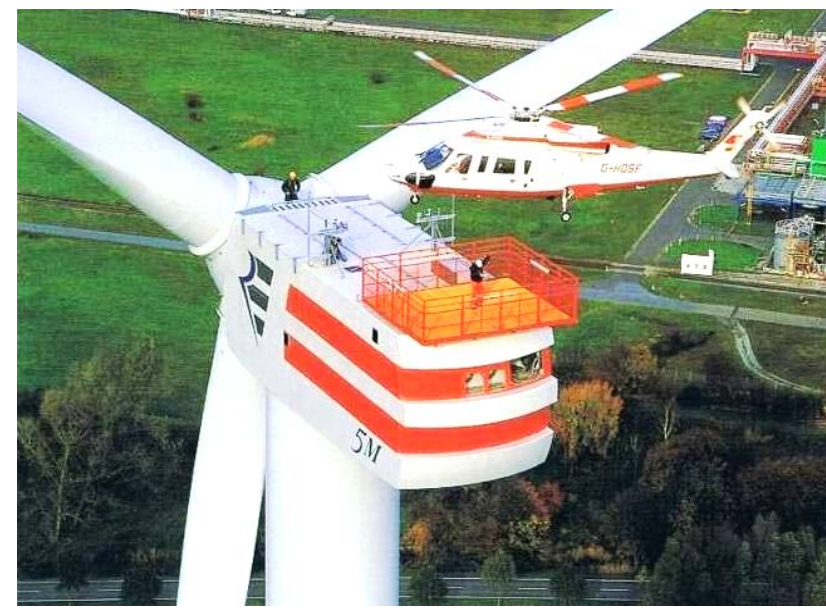

Fig. 6. Moment of involving maintenance of the helicopter crew at a height of $80 \mathrm{~m}$ land-based Norwegian horizontal axis three-bladed wind turbine with the largest installed capacity of up to $5000 \mathrm{~kW}$ [11]

All modern wind turbines on the nature of its placement of wind turbines are divided into land (see Fig. 1, 4-6) and the sea (Fig. 3, 7) based [9, 11].

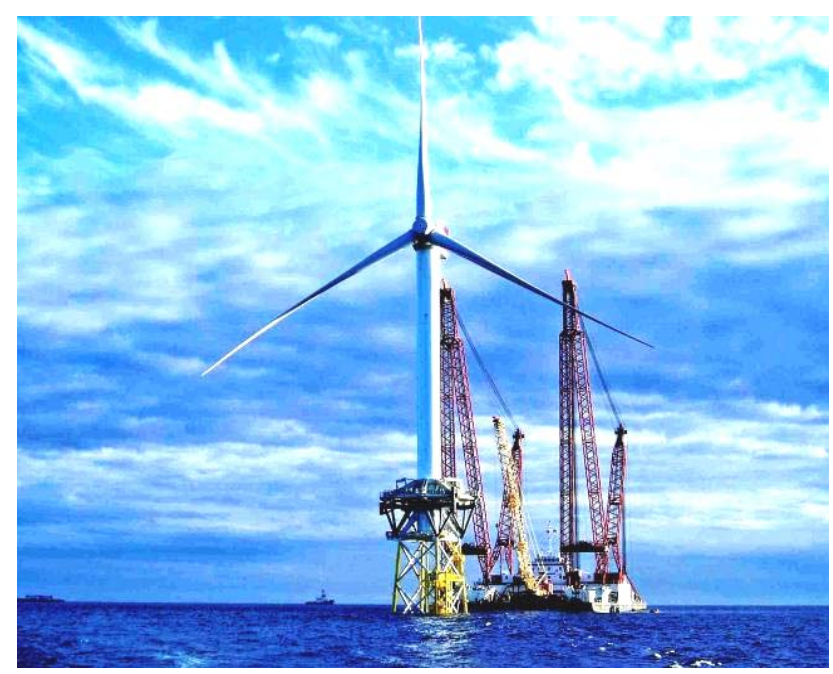

Fig. 7. Moment of preparation for assembly work on the modern sea-based three-bladed horizontal axis wind turbine installed capacity of up to $600 \mathrm{~kW}$ [11]
1.2. Technical characteristics of the wind turbine and the economic aspects of wind energy. The amount of electricity generated by wind turbines depends significantly on wind speed. Wind turbine begins to produce electricity at a wind speed of $3 \mathrm{~m} / \mathrm{s}$ and is automatically disabled when the wind speed exceeding $25 \mathrm{~m} / \mathrm{s}$ [2]. It was found that the air flows from the earth's surface (sea) are substantially laminar - their underlying atmospheric layers situated above the brake [2]. This physical effect in the Earth's atmosphere is markedly reduced at altitudes of $100 \mathrm{~m}$ and more. So powerful modern wind turbines have a tower height of not less than $70 \mathrm{~m}$.

Maximum power of wind turbines reached at a wind speed of $15 \mathrm{~m} / \mathrm{s}$ [2]. From the available data suggest that the modern large wind turbines of $2 \mathrm{MW}$ power is characterized by [2]: the height of the tower $-70 \mathrm{~m}$; the blade length $-37 \mathrm{~m}$; the weight of the turbine rotor $-52 \mathrm{~m}$; the weight of the engine room $-82 \mathrm{~m}$ Today wind turbines with turbine brand $V 90$ of $3 \mathrm{MW}$ power of the Danish company «Vestas» has the full height $-115 \mathrm{~m}$, tower height $-70 \mathrm{~m}$, and the blade diameter $-90 \mathrm{~m}$ [9].

Fig. 8 shows the appearance of the blades, designed for use in a wind turbine.

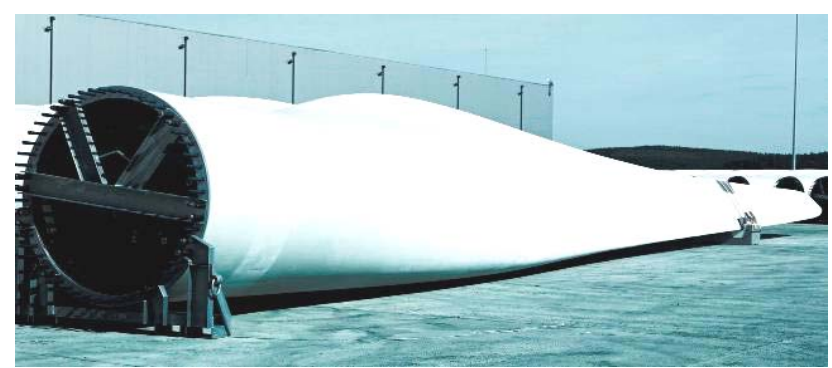

Fig. 8. Enlarged image of a single blade of the length of $40 \mathrm{~m}$ of modern horizontal-axis wind turbine, located on the plant site of the finished product $[2,11]$

We point out that in 2009, the modern turbine wind turbine class (1.5-2.5) MW took up $82 \%$ of the global «big» wind energy [2]. In addition, we note that the beginning of 2015 the total installed capacity of all wind turbines producing electricity around the world amounted to $369 \mathrm{GW}$ [2]. The average increase in the amount of wind power world, since 2009 , up to $40 \mathrm{GW}$ per year. It is caused, first of all, the rapid development of the «big» wind power in the United States, India, China and Germany [2]. In wind power industry to 400 thousand people were employed in 2008 across the globe [2]. The cost price of electricity produced on a commercial scale wind turbines, to a large extent it depends on the wind speed. Thus, at a wind speed of $8 \mathrm{~m} / \mathrm{s}$, it is about 3.6 cents/(kW·h) [2]. As for the cost of construction of large wind turbines, it is, for example, for prototype, shown in Fig. 6 and erected recently in Norway, $67.5 \mathrm{mln}$ US dollars [11]. This shows that the wind turbine is an expensive technique. The costs for its purchase pay off for the first 7 years of operation (with an estimated useful life of 25 years) $[9,11]$.

1.3. Disadvantages and problems of wind energy. The issue before us is a kind of alternative energy unregulated source of energy. Electricity generation by means of wind turbines depends significantly on this feature more 
variability of natural factors as wind speed. It is believed that the construction of WPP advantageous in regions where the average annual wind speed is not less than (5-6) $\mathrm{m} / \mathrm{s}$ [1]. Therefore, for a large windfarm characteristic uneven granting power to the grid. In this context, wind power requires a certain amount of power backup in appropriate energy systems. This feature greatly increases the cost of the wind turbines received from them electricity. Sometimes it came to the fact that the power system with great reluctance was connected wind turbines to the grid. In this connection, in some countries there are even special laws that require the power system controllers to perform data connection turbine [2]. Practice has shown that the problems in electric power systems and control due to the instability of wind turbines work begins after the proportion of them in the (20-25) \% of the total installed capacity of the system [2]. As for the small wind turbine power unit (in the case of «small» wind energy), they may also have problems with the network infrastructure. This is due to fact that the cost of power lines and switchgear for their connection to the grid may be too large. Large wind turbines for power are experiencing significant problems with a repair, since the replacement of major parts (blades, rotor, etc.). At an altitude of about $100 \mathrm{~m}$ is a complex and expensive undertaking.

Certain disadvantages of this type of alternative energy are also generated by the rotating blades buzz around working windmills (because of his exclusion zone around large wind turbines is at a radius of at least $300 \mathrm{~m}$ ), lowfrequency vibration of the ground in the area of accommodation powerful wind turbine and technical difficulties resulting at the lightning protection of bulky turbines and wind turbine blades [2,9]. Recently, experts have begun to pay attention to the deterioration of the television communication in the areas where wind farms $[2,9]$.

1.4. Wind power in Ukraine. Modern engineering of Ukraine, although slow, but progressive way, moving towards the development of clean energy based on alternative and renewable energy sources. Government programs we create favorable conditions for the development of new energy technologies, including wind power and Fig. 9 shows a map of Ukraine coated with a zone average annual wind speeds. From the data in Fig. 9 and set forth in subsection 1.3 the information that the most rational areas of the construction of wind power plants are the Carpathians and all the Black Sea coast in Ukraine, where the average wind speed reaches values of $5 \mathrm{~m} / \mathrm{s}$ or more $[2,9]$. The largest wind farm in Ukraine is the station «Novoazovsk» with an installed capacity up to $23 \mathrm{MW}$ (Donetsk region) [2, 9].

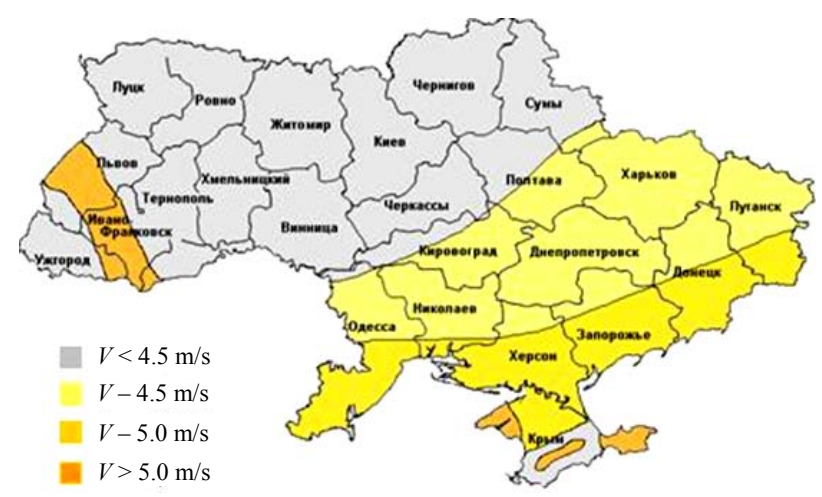

Fig. 9. Map of Ukraine with areas of average wind speeds [2]

Wind power in recent years has become one of the most popular sources of alternative energy. For all its faults, wind energy is an environmentally friendly way to generate energy. Therefore, in modern society it has received increased attention from both government institutions and civil society organizations. In conclusion, it should be noted that the share of wind power in Ukraine's energy system can be significantly increased due to the practical realization of large-scale national events in the field of energy efficiency.

2. Solar energy. This type of energy is one of the promising areas of renewable energy, based on the direct use of solar radiation for energy with its help in the form of electricity or thermal energy [3]. It is believed that this solar energy can be a real "successor» in the traditional energy, capable to pick up her baton in providing mankind with energy [12]. Modern course of development of our civilization requires people to take control of the flow of solar energy, while maintaining the unique climate of the Earth. It is known that at the inlet of the Earth's atmosphere solar radiation power density numerically averages $1367 \mathrm{~W} / \mathrm{m}^{2}$ [3]. It is necessary to remind the reader that this value is the solar constant [13]. After reaching the surface of the earth, this value is due to the absorption and scattering of atoms (molecules) of atmospheric gases, aerosols, water droplets and ice crystals is reduced and at the equator is already about $1020 \mathrm{~W} / \mathrm{m}^{2}$ [3]. At present, there are two basic physical and technical ways to use the energy of solar radiation [12]: the first - the photoelectric providing direct generating electricity using photovoltaic cells (PVC), irradiated by this radiation; second - photothermal providing receiving thermal energy by heating of liquid coolant under consideration radiation. As part of this review will focus in more detail on the first method, the practical application of solar radiation. As for the second method of converting solar radiation energy, it coolant (usually water) is heated in the reservoir (light absorbing pipe system) is installed on the roof of the building (Fig. 10) to a sufficiently high temperature $\left(90{ }^{\circ} \mathrm{C}\right)$ and used further for space heating. 


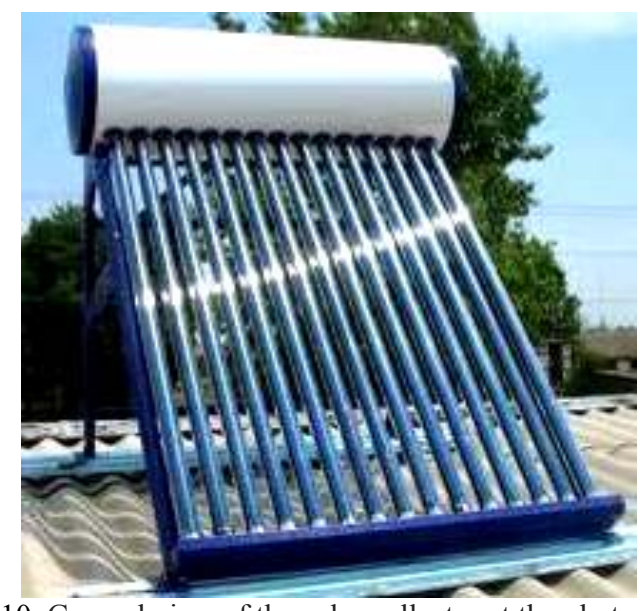

Fig. 10. General view of the solar collector at the photometric method of using the light flux of energy [3]

2.1. Brief fundamentals of physics of photovoltaic cells. As a basis of PVC monocrystalline silicon can be used with other additives in it chemical elements forming the structure of this material with $p$ - $n$-junction [3]. The principle of operation of the semiconductor silicon PVC (Fig. 11) taking into account the physical positions adopted at today, set forth in [13], is as follows. It creates a «hole» in the $p$-layer of the semiconductor (positive) conductivity and $n$-layer - electron (negative). On the border of these layers there is a potential barrier to the movement of charge carriers (electrons and «holes») of a semiconductor layer to another. Therefore, prior to exposure to solar PVC (photon flux) in said semiconductor electric current will be omitted. If you fall on the same PVC flow of photons (quanta of electromagnetic energy) due to the absorption of these quasiparticles are created pairs electron-«hole». These couples will approach the boundary of these layers and reduce the potential (energy) barrier between the $\mathrm{p}$ and the n-semiconductor layers. Thus, in a semiconductor for its charge carriers (electrons and «holes») will be created conditions for their unimpeded passage from layer to layer. As a result, the semiconductor will occur in the induced electromotive force (EMF) and the semiconductor will become a source of electric current. You can say that the ability to produce electricity occurs in the semiconductor due to its special chemical structure on the subatomic level, and create in it an internal electric field under the influence of external energy to the structure of the electromagnetic quanta of light. The value of the photo-EMF in a semiconductor will be greater than would be the light intensity or the photon flux [13].

2.2. Types of photovoltaic cells. At present, the technology of photovoltaic cells to distinguish between the following three generations of PVC [3]: the first generation - crystalline, including monocrystalline silicon, polycrystalline (multicrystalline) silicon and thin-film polysilicon elements; the second generation - thin film, microcrystalline, nanocrystalline, based on cadmium telluride and copper-based diselenide-indium-gallium elements; the third generation - photosensibilised by dye organic (polymeric), inorganic and based on cascade structures elements. It should be pointed out that all these PVC inherently contain a $p$ - $n$-junction [3].
It is interesting for the curious reader the information that is related to the physical and technical features obtaining $p$ - $n$-junction to a single-crystal silicon PVC, shown in Fig. 11. According to the scheme of construction of the PVC monocrystalline silicon, has historically dominated the initial phase of production in the world of PVC (up to $90 \%$ of market volume), in the form of a thin plate is placed on top of the metal base (lower base contact). Both end faces of the semiconductor plate of silicon filler is to change its conductivity. On one side of this plate is doped (enriched) to create electrons in the $n$ semiconductor transition layer to the silicon by adding a chemical element with a higher number of valence electrons (typically phosphorus), and on the other opposite side of the chemical element is doped with a small amount of stretching electrons (typically boron) for the creation in the semiconductor junction layer $p[14,15]$. As a result of the single-crystal silicon doping in it and you want us to create a $p-n$-junction. Then a modified semiconductor with a $p$ - $n$-junction fits very thin metal mesh (upper contact) and applied to the top antireflection coating (see Fig. 11). After joining the lower and upper metallic contacts on the external electric circuit PVC is ready to receive the light flux and development by manifesting it in the photovoltaic effect $[13,16]$ at its $p$ - $n$ junction photo-EMF.

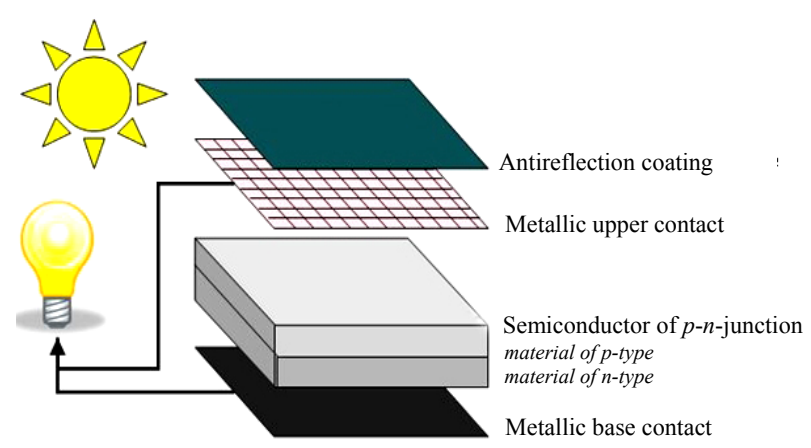

Fig. 11. Schematic representation of the first generation PVC with $p$ - $n$-junction formed by the silicon single crystal doped with other chemical elements [3]

We should also note that in recent years there has been some progress in the creation of PVC on the basis of optical nanoantenna directly transform the electromagnetic energy of light radiation into electric current $[3,17]$. The prospect nanoantenna due to their high theoretical efficiency, reaching up to $85 \%$, and potentially lower cost. Thus, under the PVC efficiency to be understood a parameter that indicates what portion of the electromagnetic energy of the luminous flux at the level of its working atomic structure of semiconductor material is converted into electrical energy. In the first half of the 20th century, the efficiency for sulfur-thallium PVC is less than $1 \%$ [3]. For today's silicon PVC and manufactured based on gallium arsenide, and their efficiency reaches $(10-20) \%$ [15]. Great scientific and technical achievement was the development of the semiconductor industry and the creation of PVC silicon with an efficiency of up to $40 \%$. An important area in the global solar energy is to provide cheap and convenient photoelectric converters formed on the tape-based polycrystalline silicon struc- 
tures, thin films of amorphous silicon and other semiconductor materials. Of the new semiconductor structures of the most high for use in the PVC structure was «aluminum-gallium-arsenic», industrial and commercial development of which has just begun in the solar technology market [15]. Great promise in the field of solar energy is open heterostructure (heterogeneous structure) semiconductors composed of a number of different chemical composition of semiconductors [15]. In practice, it turned out that when they are used as part of PVC they are twice as efficient as today's silicon semiconductors. Note that for scientific discovery, research and implementation in the area of solar energy, as well as in laser technology similar semiconductor heterostructures our countryman, Academician of the Russian Academy of Sciences, Director of the Leningrad Physico-Technical Institute of the Russian Academy of Sciences, Professor J.I. Alferov was awarded the Nobel Prize in Physics for 2000 [3, 15].

2.3. Methods for the technical implementation of photovoltaic cells. Single PVC, made on the basis of traditional crystalline silicon semiconductor, capable of producing a constant voltage is relatively small values (up to $0.5 \mathrm{~V})$. [15] In practice, therefore collected in individual PVC modules, and a number of modules - a panel (battery), the output voltage from the nominal constant which may be 12, 24 and $48 \mathrm{~V}$ [3]. Solar cells can be performed as a rigidly fixed on the fixed base (Fig. 12) and mobile location tracking of the sun horizon (Fig. 13). Due to the fact that, as used in domestic and industrial consumers of electricity are adapted to supply a single-phase AC voltage a nominal level of $220 \mathrm{~V}$ or three-phase alternating voltage network a nominal level of $380 \mathrm{~V}$, then the actual use of solar cells between them and the power consumer should be placed inverter - electrical device that converts DC voltage from our solar source to the corresponding alternating voltage. It is obvious that during daylight hours the solar panel will operate and generate electricity, and in the dark - «rest» [12].

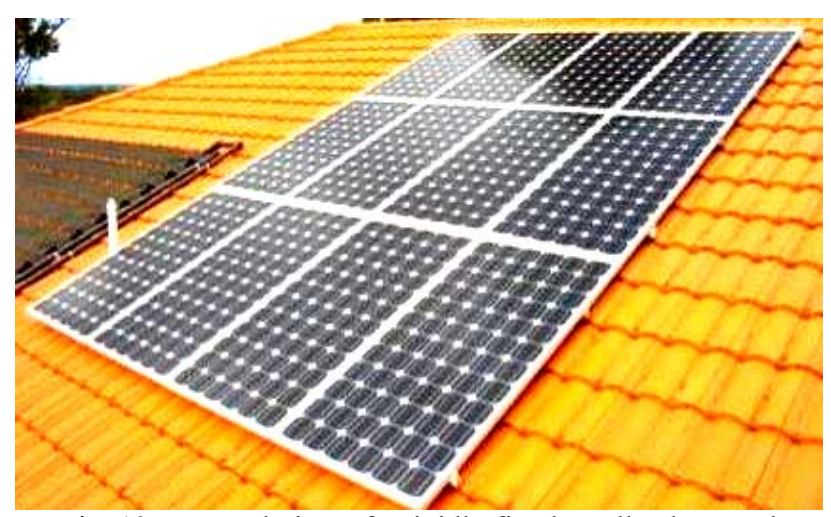

Fig. 12. External view of a rigidly fixed small solar panel mounted on the roof of the house [15]

Since electric power supply to the consumer requires room, the solar electric system is necessary to introduce a powerful storage device of electric powerthe battery [12].

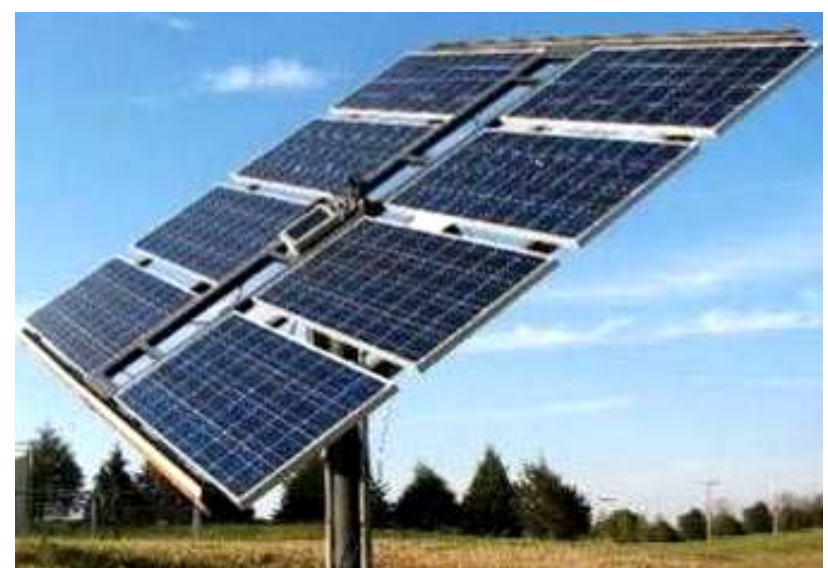

Fig. 13. External view of a small mobile solar panel with a tracking system (rotation) «following the Sun» [15]

Charge of the batteries of solar panels requires compliance with a certain algorithm. Therefore a special electronic device - a controller (Fig. 14). [3, 12] is used for process control battery charging from $\mathrm{PVC}$.

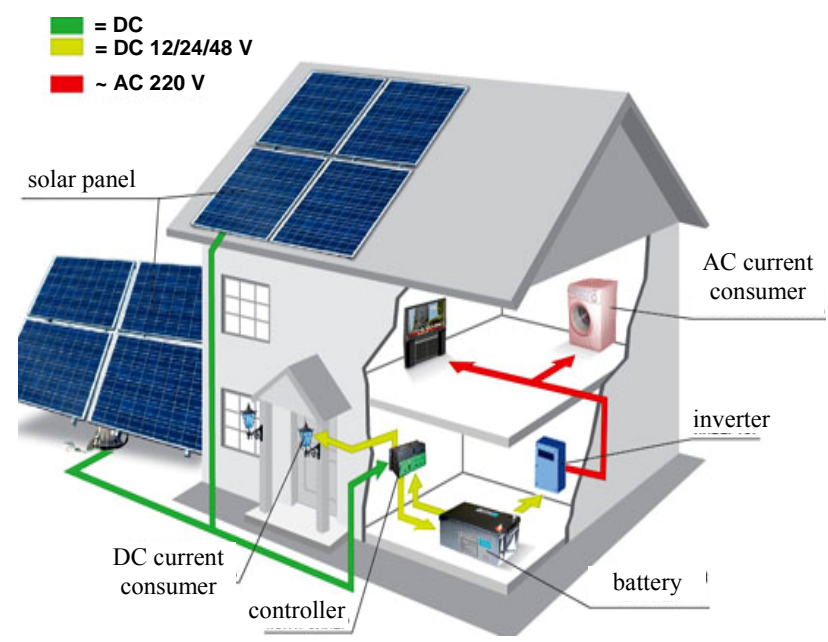

Fig. 14. Typical wiring diagram of solar panels connection to the networks of direct and alternating currents of an apartment house [3]

Currently, service life of solar cells increased to 25 years [12]. Changing the power output of the solar cell is achieved by the addition or removal of its individual modules solar cell cost is now around US \$ 1.5 per 1 watt of its installed capacity. [12] This value falls from year to year. Installation in Ukraine on the subject of «turnkey» solar panels is estimated at about $4.5 \$ / \mathrm{W}$ [12].

2.4. Industrial applications of photovoltaic elements and the economic aspects of solar energy. For such use it is necessary to create a PVS solar power plant (SPP) for direct conversion of solar radiation into electrical energy [18]. Note that the first experimental SPP, applied truth photothermal method for converting solar radiation, was built in 1985 in the USSR (Schelkino, Crimea). Its peak installed capacity of about $5 \mathrm{MW}$ [18]. By the way, I have the same power and the nuclear reactor at the world's first nuclear power plant (NPP), built in 1954 in the USSR (Obninsk, scientific leader - Academician of the Academy of Sciences of the USSR I.V. Kurchatov) and marked the beginning of the nuclear power industry [19]. Since the Crimean power system was deficient, in 
this region, solar energy has received intensive development. With this alternative source of energy in 2014 is using SPP produces up to $30 \%$ of the required volume of electricity [18]. It should be noted that at the end of 2010 this figure actually generated electricity for Crimea was only $7 \%$. Currently, in the Crimea, solar power «parks» is already about 227.3 MW [18]. The basis of solar power make up SPP Crimea «Okhotnikovo» installed capacity of $80 \mathrm{MW}$ (Fig. 15) and SPP «Perovo» installed capacity of 100 MW (Fig. 16). Both of these SPP were built by the «Activ Solar» company [18]: Station «Okhotnikovo» in 2011 about 160 hectares and the station «Perovo» in 2012 to 200 hectares.

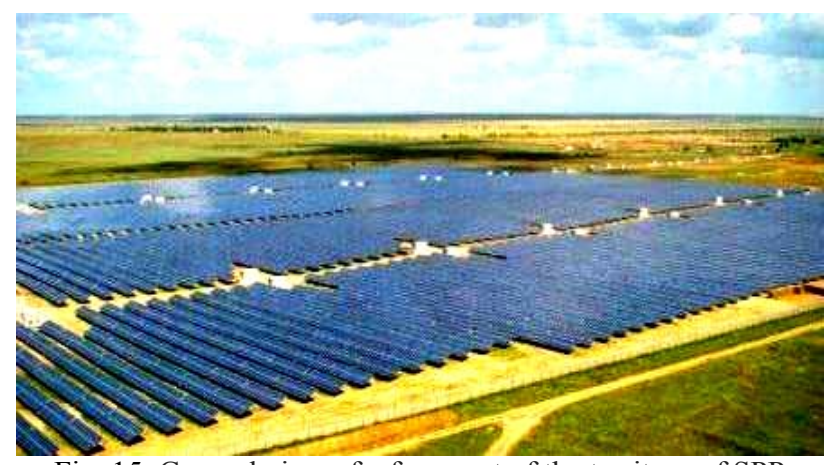

Fig. 15. General view of a fragment of the territory of SPP «Okhotnikovo» with installed power of $80 \mathrm{MW}$ (Crimea) [18]

Solar batteries of the SPP «Okhotnikovo» consist of about 365 thousand units based on polycrystalline PVC and can produce up to $100 \mathrm{GW} \cdot \mathrm{h}$ of electricity per year. This SPP meets the electricity needs of about 20000 households. Solar panels of the SPP «Perovo» consist of 455 thousand polycrystalline PVC modules connected by about $1500 \mathrm{~km}$ of cable [18].

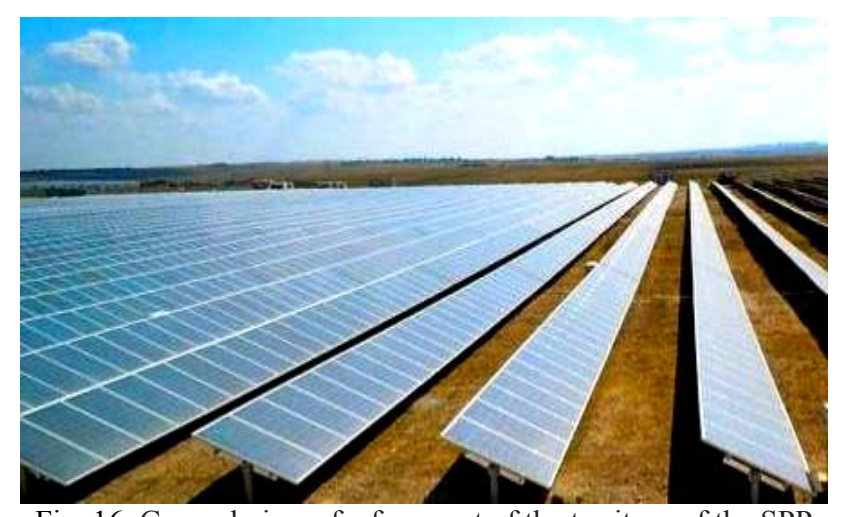

Fig. 16. General view of a fragment of the territory of the SPP «Perovo» with installed power of $100 \mathrm{MW}$ (Crimea) [18]

SPP «Perovo», which was as of June 2012, the most powerful solar power plant in the world, produces up to 132.5 GW'h of clean electricity per year. We mention the fact that on 1 August 2015, the Crimea was launched SPP «Nikolaevka» with an installed capacity of $70 \mathrm{MW}$, which is now running in test mode of operation [18].

Solar energy is actively developing in the world. The rate of growth simply amazing. So, if in 2005, PVC production in the world was approximately $1.65 \mathrm{GW}$, then in 2012, the total installed capacity of the world's solar power plants exceeded $100 \mathrm{GW}[3,18]$. At the beginning of 2014, this photovoltaic power plant in the world was estimated to have $139 \mathrm{GW}$ [18]. The leader in terms of installed capacity there are EU countries, which Germany has the highest rate of «per capita» of the population to produce electricity through the use of solar power capacity. In mid-2011, more than 100 thousand people were employed only in the photovoltaic industry in Germany. In addition, in 2011, about $3 \%$ of electricity produced in Italy, was obtained by means of photovoltaic installations [18]. According to projections obtained through solar energy is theoretically able to provide up to $2050(20-25) \%$ of the needs of mankind in electricity. This will dramatically reduce emissions of carbon dioxide in Earth's atmosphere. Energy market experts believe that the percentage of the world needs to ensure by 2050 electricity produced in the SPP will rest on the question of the cost of $1 \mathrm{~kW} \cdot \mathrm{h}$ at solar installation solar power plants «turnkey». In 2013, the price of 1 $\mathrm{kW} \cdot \mathrm{h}$, generated in the SPP in regions with lots of sunlight (for example, to Southern California in the United States), was about 10 cents. The cost of $1 \mathrm{~kW} \cdot \mathrm{h}$ of electricity generated by nuclear power plants currently cost about 15 cents [18]. The annual output of the world's electricity in the SES in 2014 amounted to 185.9 TW'h (about $0.79 \%$ of its total volume produced per year), with an annual growth rate of $38 \%$ [3]. As for the payback of funds invested in solar energy, then, for example, for the United States when the average solar radiation energy intensity $1,700 \mathrm{~kW} \cdot \mathrm{h} / \mathrm{m}^{2}$ per year energy payback of solar power plants with a polycrystalline silicon modules in their batteries with an efficiency of $12 \%$ is about 4 years $[3,18]$.

2.5. Largest SPP in the world. We point out the largest of the existing solar power plants on the world:

- Solar plant «Million Solar Roofs» 1000 MW (1st turn - 2015, California, USA);

- Solar plant with installed capacity of $550 \mathrm{MW}$ (Mojave, CA, USA);

- Solar plant with an installed capacity of 290 MW (2012, Caliente, Arizona, United States);

- Solar plant with installed capacity of 200 MW (Golmud, China);

- Solar plant with an installed capacity of $166 \mathrm{MW}$ (Schipkau, Germany);

- Solar plant with an installed capacity of 145 MW (Neuhardenberg, Germany);

- Solar plant with an installed capacity of $100 \mathrm{MW}$ (2012, Perovo Crimea);

- Solar plant with installed capacity of 80 MW (2011, Okhotnikovo, Crimea);

- Solar plant with installed capacity of 70 MW (2015, Nikolaevka, Crimea).

Note that the world's largest SPP above the Arctic Circle is a station with an installed capacity of $1 \mathrm{MW}$ (Batagai, Yakutia, RF) [18]. Nevertheless, the RF falls far behind the level of electricity generation with the help of the SPP leading countries of the world. Just exotic looks SES entered into service in September 2010, $100 \mathrm{~kW}$, in the Belgorod region (RF) [18]. In September 2014, it was put into trial operation of Kosh-Agach SPP 5 MW (Altai, Russia). In the nearest plans of the Russian Federation 
appears to increase by 2020 the total volume of installed capacities of SPP to $1500 \mathrm{MW}$ [18].

2.6. The use of photovoltaic cells in transport. PVC can be installed on various vehicles: boats, electric cars, trains, airplanes, etc. [3]. One of the possible use of solar options embodied in Fig. 17. In these cases, the PVC produce electricity, which is used for either the on-board power supply of the vehicle, or for electric motors $[3,12]$.

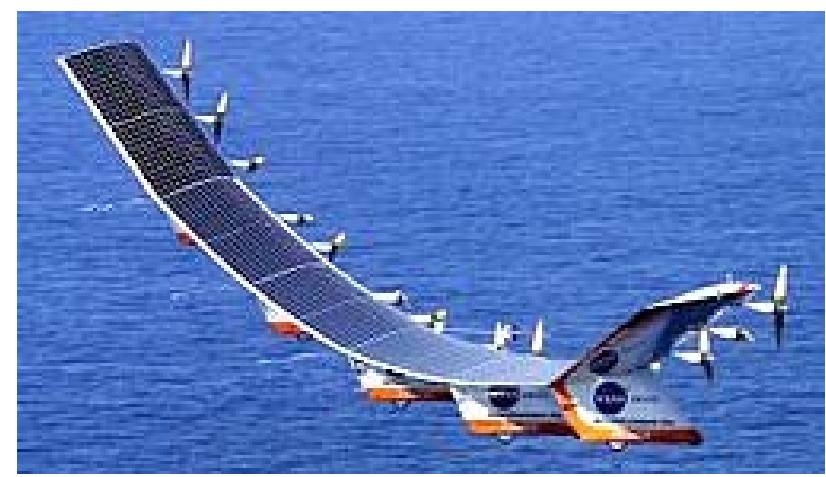

Fig. 17. Unmanned aircraft of the NASA «Pathfinder Helios» with PVC, mounted on its original wings [3]

In Japan and Italy already have railway trains defined on the roofs of their cars with solar panels, which generate electricity used to power the air conditioning, lighting and alarm systems [3]. Currently, the company «Solatec LLC» sells thin-film PVC of $0.6 \mathrm{~mm}$ thickness to install them on the roof of a hybrid car brand Toyota Prius. The aerodynamics of the car from the use of PVC is not broken. Obtained from the PVC electricity in this case goes to recharge car batteries, which increases its mileage by about $10 \%$ [3]. In 2010, a manned aircraft «Solar Impulse» with the PVC stayed in the air for about a day, which gives us hope for the use of such devices as a technical supplement to the satellites [3].

2.7. The invention of heteroelectrics and new prospects for solar power. Recent scientific discoveries and inventions in the field of PV can make dramatic changes in the area of solar energy. Russian scientists have reported the discovery of a new class of solar cells heteroelectrics and creation on their basis of a new generation of PVC, as well as their manufacture using high performance solar cell - «star battery» (Fig.18) [3, 15].

The main components of the «star battery» are heteroelectrical cell and the capacitor [15]. Heteroelectrical solar cell converts solar energy into electrical energy and stores it heteroelectrical capacitor. «Stellar battery» can function in the absence of sunlight, capturing only the infrared radiation at the same time their work. When converting visible light, its efficiency is about $54 \%$, and for converting the infrared radiation approximately $31 \%$ [15].

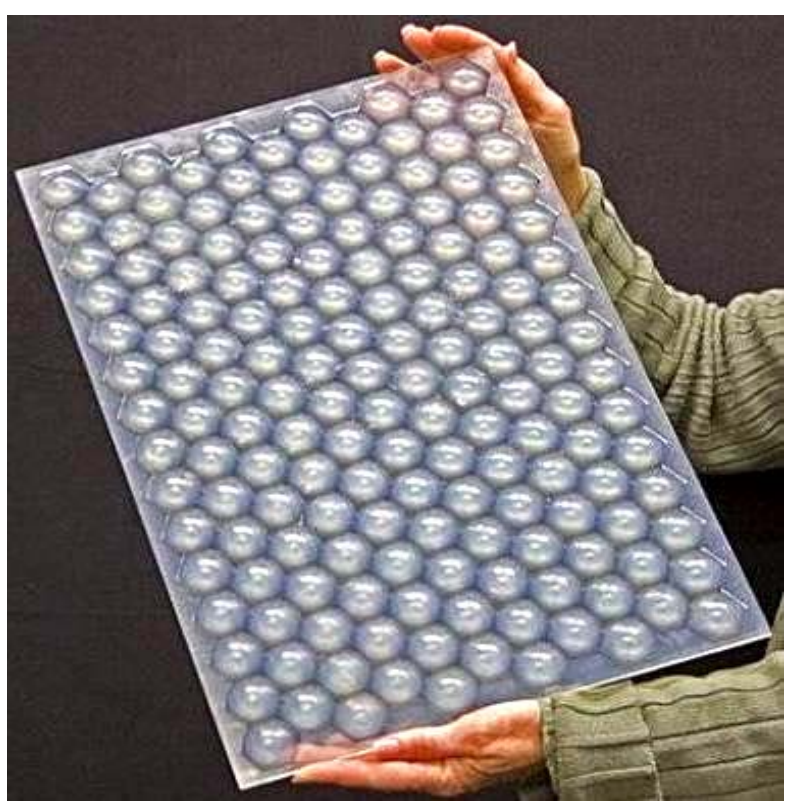

Fig. 18. External view of a revolutionary invention by scientists of the RF in the field of solar cells - «star battery» [15]

In the «star battery» photocurrent is four times higher than in the solar panel, and its mass per one watt of power generated almost 1000 times smaller. Note that set in «star battery» heteroelectrical capacitor has a small size and large capacitance. Thus, for a volume of only $180 \mathrm{~cm}^{3}$ capacity heteroelectrical capacitor «star battery» is about $0.11 \mathrm{~F}[15]$. Due to what has been achieved in a «star battery» such extraordinary results? In the authors' opinion that the invention of the Scientific Center of semiconductor products $(\mathrm{RF})$ - by supercoherence phenomenon occurring in a semiconductor with a pre-entered it with nanoparticles of other chemical elements when exposed to external electromagnetic fields [15]. Due to the phenomenon supercoherence of heteroelectrics appears in a new physical property - the ability to unite on a single frequency electromagnetic waves of sunlight, which is known to be characterized by different frequencies and wavelengths, respectively [13]. Application of heteroelectrics («star batteries») in the solar power offers great prospects for the development of this type of alternative energy $[3,15]$.

3. Geothermal energy. This type of renewable energy is based on the temperature difference between the boiling liquid metal core of a diameter of up to $7,000 \mathrm{~km}$ with a temperature of about $5000{ }^{\circ} \mathrm{C}$ of the planet cooled and its solid surface $[20,21]$. Ground water as a result of this difference caused by temperature thermal processes occurring in the solid Earth's crust to $100 \mathrm{~km}$ thick, heated to high temperatures. Sometimes these temperatures are substantially above its boiling temperature. It is believed that the temperature of the rocks and the water in the earth's crust, heated by magma Earth rarely exceed $370{ }^{\circ} \mathrm{C}$ [20]. Only in some areas of the globe temperature of groundwater is sufficient to generate electricity with it. These areas are typically in areas of tectonic plates fault solid crust. Therefore, the practical use and the active development of geothermal energy should be expected in areas with low-lying geothermal resources of our planet are concentrated primarily in Iceland, 
the RF (Kamchatka) and the US (California) [4]. Of deep geothermal resources of the earth because of the high cost in this exploratory geological and scouting and drilling operations are not suitable [4] for the purposes under consideration.

3.1. The main uses of heat of the Earth's core. By way of the use of geothermal energy are following two main technologies [20]: the first - its direct use in which emerging from the depths of the Earth's surface hot water and steam are used in building heating systems, horticultural and industrial processes; the second - production with the help of electricity, in which is used to drive geothermal steam turbine rotor movement of heat from the Earth's core. Fig. 19 shows a diagram of a first method of using geothermal heat [4].

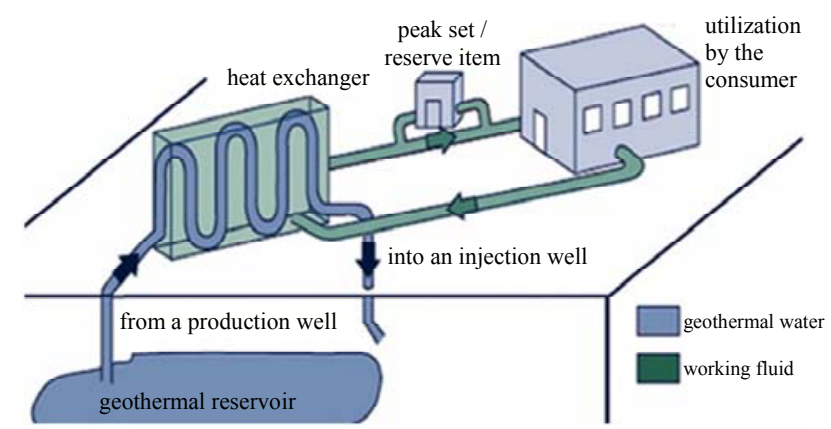

Fig. 19. Schematic representation of a first method of using geothermal heat for heating buildings [4]

In modern systems, the direct use of heat in the reporting discovered and surveyed experts geothermal reservoir well is drilled to provide a constant stream of ground-based devices with his hot water (see Fig. 18). In the case where the geothermal well is not a closed vessel for artesian groundwater under high positive pressure, the downhole pump is used. In geothermal wells depths than $250 \mathrm{~m}$ submersible pumps are used for applying hot water in a geothermal heat exchanger and further into the injection well. Heated in the heat exchanger working fluid is supplied for space heating.

Fig. 20 shows a possible diagram of a second method of using geothermal heat. In this case, raised from the depths of the special heat-resistant pipes is two-phase mixture (water and steam) is fed into a separator (see Fig. 19), from which selected the superheated steam is sent to a steam turbine blades, turbine generator rotor is rotating.

After hot geothermal water separator, and condensed in the condenser steam turbine by injection wells are sent back to the earth. Currently, there are two basic types of geothermal energy technologies [20]: the first type - «instant steam»; the second type - «dry steam». Fig. 20 illustrates a first type of technology that uses a pressurized flowing from a geothermal well with hot water temperatures above $180^{\circ} \mathrm{C}$. In this case, due to the pressure drop in the geothermal water raised partial boiling occurs and its formation in the separator «instantaneous steam», directed to the turbine. Geothermal power plants (GTPP), using the second type of technology, work on underground resources «dry steam» [20]. Since deposits of subterranean reservoirs «dry steam» hard to find, the GTPP operate typically in the «instantaneous steam» technology $[4,20]$.

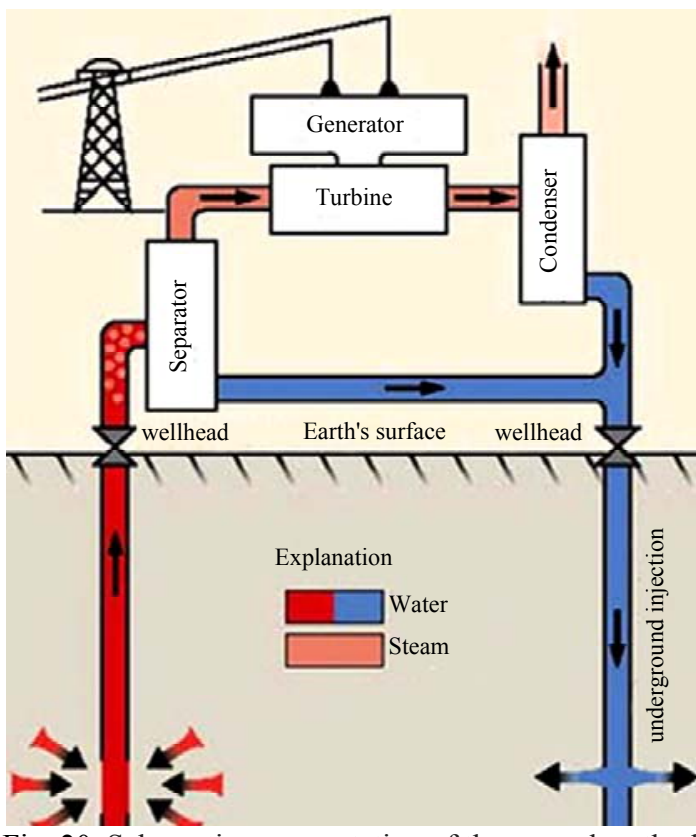

Fig. 20. Schematic representation of the second method of geothermal heat utilization, intended for electrical energy generation [4]

3.2. Industrial use of geothermal energy. Implemented by such use of geothermal heat using GTPP. The world's first GTPP with installed power of 7.5 MW was built in Italy in 1911 [22]. Today, the world leader in the number of GTPP (77 plants) and the volume of electricity produced by them takes the United States. Installed US GTPPs' power in 2010 was about 3,100 MW [22]. Produced in the United States at its GTPP electricity was in 2010 , more than $40 \%$ of all such powers of the then world [22]. The share of electricity generated by GTPP for the period amounted to the total electricity production is only $0.3 \%$ in the US [22]. Most geothermal energy "per capita» of the population is now produced in Iceland, where about $95 \%$ of homes are heated by geothermal energy [4]. According to [20] in Iceland currently up to $60 \%$ of the total consumed energy is taken from the earth. The world practice of industrial use of geothermal heat shows that the most effective ones are characterized by GTPP in which the depth of water intake temperature of geothermal wells is not less than $250{ }^{\circ} \mathrm{C}$ [23]. Fig. 21 is a perspective view of a modern GTPP, built in Iceland [22].

Fig. 22 is a general view of the largest to date in the Russian object of geothermal energy - Mutnovskaya GTPP of power of $50 \mathrm{MW}$ (Kamchatka), launched into operation in 2002 [22]. Annual electricity production of the gas turbine power plant as of 2010 amounted to 360.5 million KW·h [4]. Currently, it is working on the modernization of GTPP and increasing its capacity to $80 \mathrm{MW}$. 


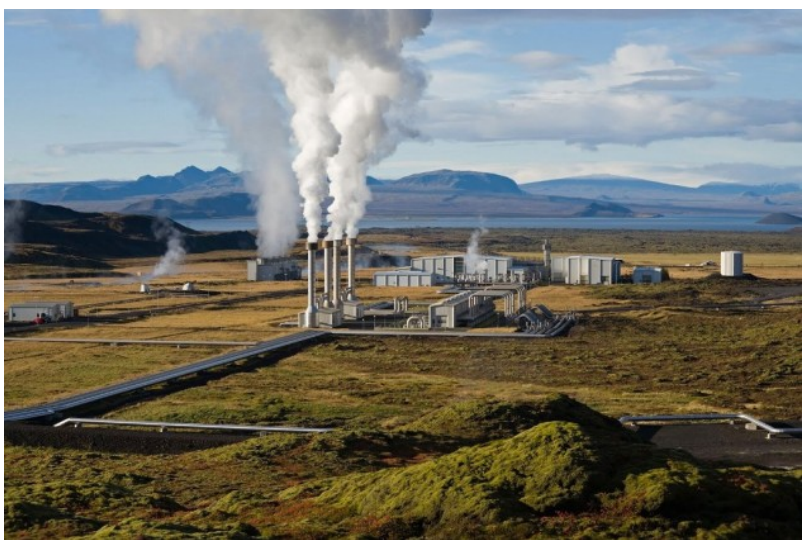

Fig. 21. External view of modern GTPP with installed power of $100 \mathrm{MW}$ (2001, Nesyavellir, Iceland) [22]

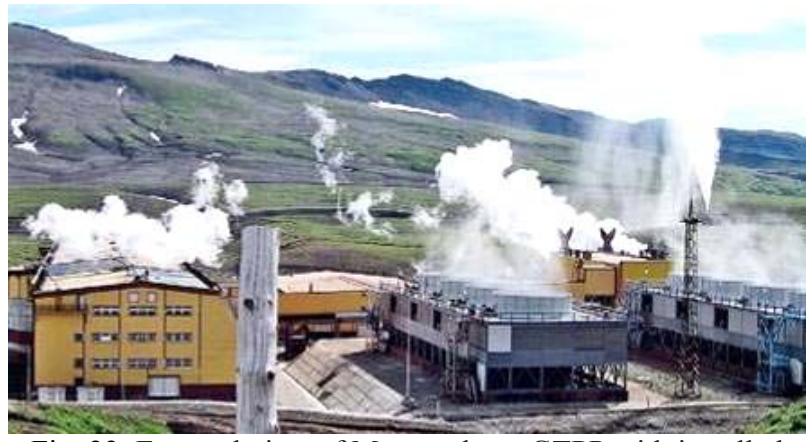

Fig. 22. External view of Mutnovskaya GTPP with installed power of $50 \mathrm{MW}$ (2002, Kamchatka, RF) [22]

Note that at the beginning of 2009, the total capacity of GTPP in the world has increased to $10.5 \mathrm{GW}$ [22]. For comparison, at the beginning of 2000, a similar figure was around $6 \mathrm{GW}$. There is a clear trend in the annual growth of installed GTPPs' power worldwide to $500 \mathrm{MW}$. The main advantage of geothermal energy is a practical inexhaustibility of its underground resources and total independence from environmental conditions, time of day and year. According to estimates of geoscientists cooling rate of the Earth's core is about $(300-350){ }^{\circ} \mathrm{C}$ per billion years [22]. Promising sources of superheated geothermal waters have many volcanic zones of the Earth, including Kamchatka, Kuril, Japanese and Philippine Islands, as well as the Caucasus, the New Zealand territory of the Cordillera of the Andes and in North and South America [4]. One of the disadvantages we have considered the type of alternative energy is still relatively high cost generated by a gas turbine power plant of $1 \mathrm{~kW} \cdot \mathrm{h}$ of electricity. It is now comparable to that of thermal power plants (TPP), which in Russian conditions on the production cost of TPP electricity is up to $1 \mathrm{RUB} /(\mathrm{kW} \cdot \mathrm{h})$, but is 10 times higher than the cost of electricity production at hydropower plants. For the record, we note that the cost of this hydroelectric power station in Russia up to $10 \mathrm{kopecks} /(\mathrm{kW} \cdot \mathrm{h})$ [20].

4. Biogas energy. The global renewable energy market is growing rapidly, according to expert estimates [1, 5]. Biogas energy, as a small sector of the energy market, and biogas plants (BGP) are currently the typical elements of modern waste-free production in many areas of agriculture and food industry. The end product in the BGP output (Fig. 23) is a biogas, containing in its composition of approximately $60 \%$ methane [5].

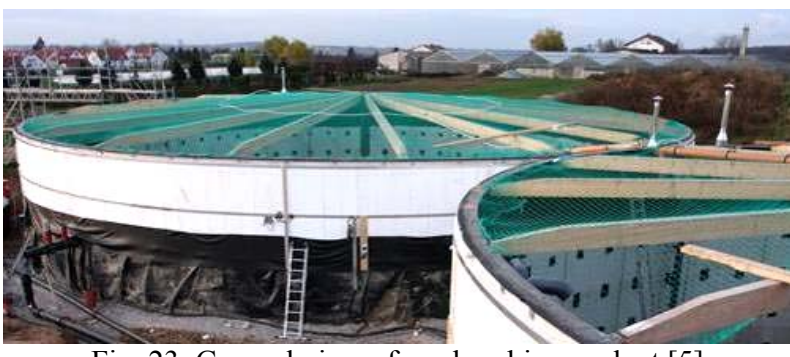

Fig. 23. General view of modern biogas plant [5]

The raw material for producing biogas in the BGP is liquid and solid manure from cattle, pigs and poultry. In addition, BGP can run on waste food production enterprises and specially grown energy crops (e.g. grass, corn and sunflower), increasing their output of biogas. On modern BGU from one ton of cattle manure get to (30-50) $\mathrm{m}^{3}$ of biogas [5]. By the way, one cow can provide to obtain $2.5 \mathrm{~m}^{3}$ of biogas per day. Resulting in the BGU biogas can then be used for the production of electricity using gas turbines and biofuels to fuel cars. In Sweden and Switzerland, biomethane has long been used in urban buses and trucks [5]. From one $\mathrm{m}^{3}$ of biogas can produce about $2 \mathrm{~kW} \cdot \mathrm{h}$ of electricity [5]. Note that currently in Germany have been built around 4200 BGU, using biogas to produce about $13,000 \mathrm{GW} \cdot \mathrm{h}$ of electricity per year [5]. The future plans of Germany shows an increase by 2020 the number of highly BSU new generation of up to 12 thousand, capable of an annual output of green electricity to $39,000 \mathrm{GW} \cdot \mathrm{h}[5]$.

5. Tidal hydropower. Today we are well aware that the grand phenomenon in our nature, connected with the rhythmic for terrestrial days the movement of sea and ocean waters as the tides, contribute to the gravity of the Sun and Moon $[13,19]$. Twice a day the sun and moon gravity force of his force to attack the seawater to the shore, then move away from him backwards. This phenomenon is known to people since ancient times, but use it to produce electricity mankind learned only recently. That tidal hydropower for the implementation of the physical and technical goals and aims. In practice, this aim is embodied by tidal power plants (TPP), the principle of which is illustrated in Fig. 24 [6].

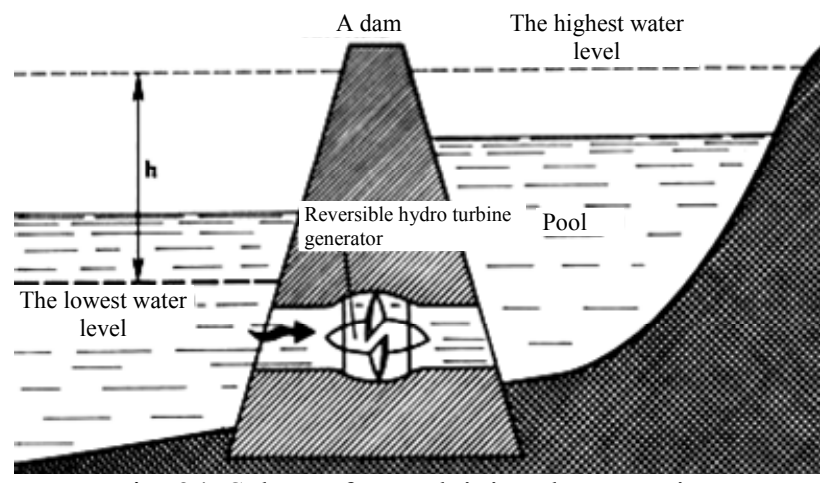

Fig. 24. Scheme for explaining the operation of a modern TPP [6]

TPP's mode usually consists of several process cycles. The first cycle - a period of high tide, when the sea water coming from the pool fills the TPP (see Fig. 24). During this period, the movement «coming» to the bank 
and, accordingly, the dam water TPP rotates installed at the base of the concrete dam wheel capsule units and power plant generates an alternating electric current. The second cycle - during low tide, when the sea water «retreat» from the shore, and, respectively, from the TPP dam. The difference in water levels in the basin filled with TPP at high tide and in the «retreat» at low tide the sea can be up to $h \approx 19 \mathrm{~m}$ [6]. During low tide, the water leaving the TPP pool in the sea (ocean), again rotating impeller hydro turbine generators, but now only in the opposite direction. And the power plant continues to produce an alternating electric current. Operating units of modern TPP provide equally good and reliable operation of its generating hydro turbine generators during rotation of the wheel in either of the two parties. The third cyclea period of idle wheels hydro turbine generators caused «lull» of seawater («dead zone»). During this period, the TPP stops power generation. For an exception during this cycle outages from TPP electricity to consumers using backup power grid from operating in its composition thermal, nuclear, hydroelectric, geothermal power plants and wind farms connected to the TPP. Interestingly, the TPP world's first built in 1913 near the city of Liverpool (Scotland) [24]. The installed power of the TPP was 635 $\mathrm{kW}$. Scientists-hydrologists and power engineers estimated that for the efficient operation of the TPP need to drop sea water levels between the tide was more than four meters. The most suitable place for the PES placement is considered to be where the tides have their greatest amplitude and where the coastal rocky terrain allows you to create a large pool closed for this kind of power fills during high tide sea water [24]. In recent years, tidal, hydropower has been further developed. It replenishes fundamentally new technical solutions while creating the world of TPP. However, their main difference is the lack of expensive concrete dams. Instead of compact hydro turbines generators of new generation of TPP are driven by large diameter wheels blades from 10 to $20 \mathrm{~m}$ [24].

Fig. 25 shows the appearance of a modern TPP installed power of $240 \mathrm{MW}$, located on the French coast [6]. The length of the concrete dam of the TPP, which serves at the same time and on high-speed highway bridge is $800 \mathrm{~m}$.

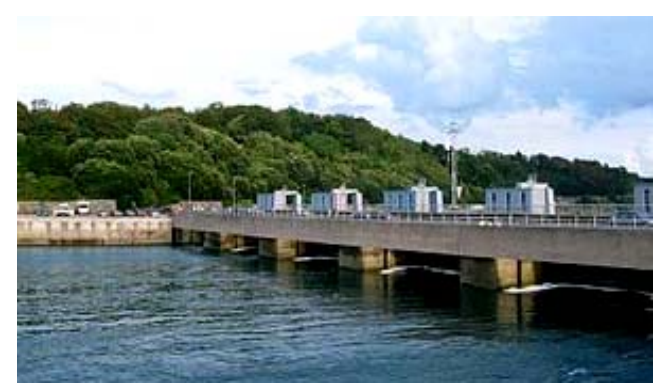

Fig. 25. General view of the TPP «La Rance» of power of 240 MW (1967, Rance River, Northern Brittany, France) [6]

By the way, the maximum amplitude of the tide in the north of France can be up to $14.7 \mathrm{~m}$ [24]. As for the record in the world of the sea tide amplitude values (of the ocean), they account for about $19.5 \mathrm{~m}$. Such absolute levels of the tide have been reported in Canada on its Atlantic coast (in the Bay of Fundy). [24] An important fac- tor in the creation of TPP is favorable geological conditions for the establishment of its partitions off the dam. Therefore, in the construction of TPP experts use data not only for the tide amplitude, but also the strength characteristics of soils, seismicity and their reliability in the operation of TPP.

Fig. 26 for comparison with the great French TPP is given a small Russian TPP with installed power as of 2009, 1.7 MW [6]. Back in the Soviet era construction project Penzhina PES was developed (Penzhina Bay in the Sea of Okhotsk, Far East, RF) [6]. The design capacity of this power plant was $87 \mathrm{GW}$. Such power indicator displays it on the level of the largest TPP in the world [6]. Currently, the status of the tempting project to create giant TPP is unknown to us. It should be noted that in the area of proposed construction in Russia Penzhina PES amplitude of sea tide reaches its highest level in the former USSR in the $11 \mathrm{~m}$ [24]. Of the other major force in the world of PES should indicate power plant with installed power of $254 \mathrm{MW}$, was built in 2011 in South Korea [6]. This TPP is able to provide power for a city with a population of 500 thousand people. The plans of the South Korean government appear launch in the near future TPP with an installed power of $812 \mathrm{MW}$ [6].

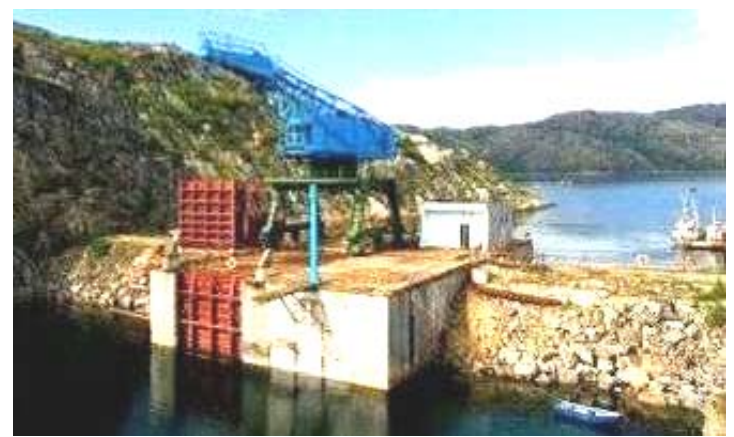

Fig. 26. General view of the TPP «Kislogubskaya» of power of 1.7 MW (1968, Sour lip, Kola Peninsula, Russia) [6]

The total potential of tidal energy in the world is now tentatively estimated installed capacity of 1,000 GW $[24,25]$. The annual output of all TPP electrical energy the world by the beginning of 2015, approximately 2,000 billion $\mathrm{kW} \cdot \mathrm{h}$, including in Russia - to 250 billion $\mathrm{kW} \cdot \mathrm{h}$ $[24,25]$.

6. Hydrogen energy. This type of alternative energy refers to the rapidly growing energy sector today [7]. Before humanity are becoming increasingly global issue arises concerning the change of power, «the foundation» of social development [26]. The main energy raw materials in the world today are oil and natural gas reserves which could create insurmountable problems in front of people about 50 years [26]. Oil and gas energy is already creating a lot of environmental problems on our planet. That's why experts drew their attention to the hydrogen reserves in the world is almost inexhaustible. Hydrogen energy is based on the use of hydrogen as a means for the generation, storage, transportation and energy consumption by humans, the transport infrastructure and various production technologies. Hydrogen is selected here as a working tool (energy source) is not by chance, but as the most common chemical element on the surface of our planet and in space [13]. In addition, this substance has 
a high calorific value (approximately $143 \mathrm{MJ} / \mathrm{kg}$, whereas the coal is $29.3 \mathrm{MJ} / \mathrm{kg}$ [7, 13]), and its combustion product oxygen is water. Moreover, the water formed by a chemical reaction can be re-introduced into the circulation of this species of alternative energy. Today is an insurmountable problem in the field of hydrogen energy is uneconomical for industrial production of hydrogen $\mathrm{H}_{2}$.

6.1. Key technologies for hydrogen production. For these technologies produce hydrogen $\mathrm{H}_{2}$ should be referred to today as follows [7, 27]: a) conventional steam reforming of natural gas; $b$ ) coal gasification; $c$ ) electrolysis of water; $d$ ) thermochemical processing of biomass; $e$ ) thermal water treatment (thermolysis) in solar concentrators; $f$ ) alternative catalytic conversion of natural gas from the heat of high-temperature gas-cooled nuclear reactor; $g$ ) aqueous alkaline electrolysis under pressure using nuclear electric power. Currently, hydrogen $\mathrm{H}_{2}$ produced mostly (up to $95 \%$ of the total volume) by the traditional conversion of natural gas (methane $\mathrm{CH}_{4}$ under pressure in the presence of a catalyst and temperature (700-1000) ${ }^{\circ} \mathrm{C}$ is mixed with water vapor) [7]. Cost of this technology for producing hydrogen $\mathrm{H}_{2}-5 \$ / \mathrm{kg}$ [27]. Gasification of coal is the oldest and relatively expensive method of producing hydrogen $\mathrm{H}_{2}$, in which coal is heated by steam at a temperature (800-1300) ${ }^{\circ} \mathrm{C}$ without access of air [27]. Electrolysis of water, based on the chemical reaction $2 \mathrm{H}_{2} \mathrm{O}+$ energy $\rightarrow 2 \mathrm{H}_{2}+\mathrm{O}_{2}, \mathrm{H}_{2}$ is characterized by cost hydrogen production to $7 \$ \mathrm{~kg}$ [27]. The heating of the biomass (waste wood) without access of oxygen at the temperature. (500-800) ${ }^{\circ} \mathrm{C}$ results in obtaining a hydrogen $\mathrm{H}_{2}$, carbon monoxide $\mathrm{CO}$ and methane $\mathrm{CH}_{4}$. Thus the production cost of hydrogen $\mathrm{H}_{2}$ is about $7 \$ / \mathrm{kg}$ [27]. Direct thermolysis of water in the solar energy concentrators (at a temperature above $2500{ }^{\circ} \mathrm{C}$ decomposes water into hydrogen $\mathrm{H}_{2}$ and $\mathrm{O}_{2}$ oxygen) produces hydrogen at its cost at least $10 \$ / \mathrm{kg}$ [27]. Application for the purpose of industrial production of hydrogen $\mathrm{H}_{2}$ high-temperature nuclear gas cooled reactors, providing the high temperatures of its helium coolant (about $1000{ }^{\circ} \mathrm{C}$ ) is used in the catalytic conversion of methane $\mathrm{CH} 4$, and cheap electricity NPP generated by it at night, is currently still at the stage of technological development $[27,28]$. Note that at the present time in Russia the latest industrial hydrogen production technology is actively engaged in RRC «Kurchatov Institute» [26, 27].

6.2. The use of hydrogen in fuel cells to produce electricity and thermal energy. Production of electrical and thermal energy using hydrogen $\mathrm{H}_{2}$ is realized in the fuel cell (FC) $[27,28]$. The fuel cell chemical reaction type: $2 \mathrm{H}_{2}+\mathrm{O}_{2} \rightarrow 2 \mathrm{H}_{2} \mathrm{O}+$ Energy. It can be seen that this reaction is the reverse of that which takes place during electrolysis of water [7]. In late 2006, around the world it operated for about 5,000 small stationary hydrogen power plants based on fuel cells [27]. By mid 2008 in Japan was established about 3000 household stationary power plants (SPP) to $10 \mathrm{~kW}$ on hydrogen fuel cells, and their cost has dropped to $19,000 \$$ for $1 \mathrm{~kW}$ of power [27]. Note that in 2006 the world was established in the SPP 800 hydrogen fuel cell power more than $10 \mathrm{~kW}$. Their total power was of $100 \mathrm{MW}$ [7.] Now the world's booming market for mobile power units (MPU) that use hydrogen fuel cells to charge mobile phones, laptops and other electronic equipment [7, 27]. In 2008, world production of MPU with hydrogen fuel cell was about 9000 pieces. (The main consumer of these light sources and intensive is US Army.) [27]

Hydrogen fuel cells now have found a definite practical use in transport (Fig. 27). Moreover, the cost of hydrogen fuel cell car on the market decreased from $275 \$$ for $1 \mathrm{~kW}$ in 2002 to $110 \$ / \mathrm{kW}$ in 2005 [7, 27].

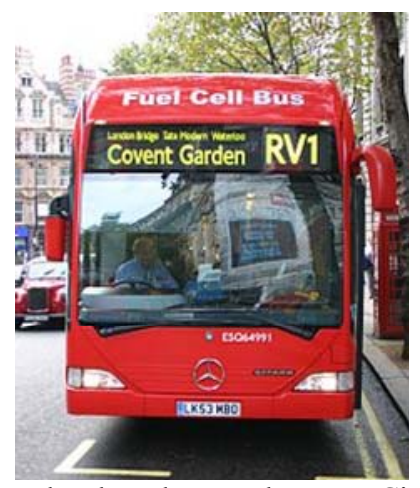

Fig. 27. Passenger bus brand Mercedes Benz Citaro, working on hydrogen fuel cells (2006, London) [7]

US Department of Energy plans to increase by 2020 the cost of hydrogen fuel cell car to $30 \$$ for $1 \mathrm{~kW}$ of power [7, 27]. In June 2008, the company «Matsushita Electric Industrial Co Ltd (Panasonic)» the beginning of the industrial production of hydrogen fuel cells in Japan. The company plans in 2016 to sell about 200 thousand household SPP and the MPU on hydrogen fuel cells [27]. It should be mentioned the fact that the hydrogen fuel cells produce power on board the shuttles USA, starting since 1981 [27]. In March 2008, during an expedition STS-123 of the space shuttle «Endeavour» Hydrogen fuel cells manufactured by USA «UTC Power» overcame the barrier of 100 thousand operating hours of the open space. The plans of the Ministries of Industry, Commerce and Economy of South Korea designated the strategic goal the creation of a society by 2040 hydrogen economy producing at SPP with hydrogen fuel cells to $22 \%$ of all electricity [27]. This gives us reason to believe such chemical sources of electric current as the fuel cell, which is the direct conversion of chemical energy into electrical energy with high efficiency value (up to $85 \%$ [26]), «mover» of hydrogen energy [27, 28].

7. Small hydropower. Small hydropower has received in recent decades some progress in the world mainly because of the desire of people to avoid environmental damage caused by large hydro reservoirs. Most often, small hydropower plants (SHPP) include energy facilities with an installed capacity of less than 5 MW [8]. At the same time according to the requirements of the European Small Hydropower Association SHPP be considered as the installed capacity of which does not exceed $10 \mathrm{MW}$ [8]. Note also that in the Soviet Union according to SNIP 2.06.01-86 requirements to those treated SHPP installed power of $30 \mathrm{MW}$, and the diameter of the impeller of the turbine was up to $3 \mathrm{~m}$ [8]. These data show that the uniform requirements of the world to the concept of small SHPPs on missing today. 
However, in many countries of the world have their own specific SHPP energy «niche» in the annual balance of electricity generation [29].

7.1. The development of small hydropower in the world. In the Republic of Belarus as of 2010 operated 36 small SHPPs with a total installed power of 13.5 MW with an annual output of over 33 million $\mathrm{KW} \cdot \mathrm{h}$ of electricity [8]. In Sweden in 1350 operates SHPP, which generate up to $10 \%$ of the country's electricity need. In the Russian Federation, which, in accordance with the requirements of GOST P51238-98 to carry SHPP station with a capacity of $30 \mathrm{MW}$, has about 100 such power stations with a total installed power of about $90 \mathrm{MW}$ [8]. Their electricity production is about 200 million. $\mathrm{KW} \cdot \mathrm{h}$ per year [29]. We point out that the technical potential of the Russian Federation of small hydropower experts estimate about 360 billion. $\mathrm{KW} \cdot \mathrm{h}$ per year (this figure is close to $30 \%$ of consumption in the Russian Federation's annual electricity volume) [8]. Note that in 2006 the total installed power of SHPP worldwide was about $73 \mathrm{GW}$. The leader here was China (47 GW), and followed by Japan (4 GW) and the US (3.4 GW). [29] It is interesting that the total global investment in small hydropower in 2006 amounted to about 6 billion $\$$.

7.2. Small hydropower in Ukraine. The economic hydropower potential of small rivers of Ukraine experts is currently estimated at up to $1.5 \mathrm{bln} \mathrm{KW} \cdot \mathrm{h}$ annual electricity generation [30]. Lifting the page of history in our country, small hydropower, we note that in 1934 was commissioned in Korsun-Shevchenko SHPP installed power of 2.65 MW [30]. This SHPP on the technical performance was one of the best stations of its time. At the beginning of the 1950s the number of small hydro power plants operating in Ukraine amounted to 956 units with a total power of about $30 \mathrm{MW}$. It is interesting to note that at the end of 1929 the number of such hydroelectric power station on the territory of Ukraine was equal to 150 units with a total capacity of 8.4 MW [30]. Later, due to the concentration of production of electricity on highpower hydraulic and thermal power plants, SHPP construction was stopped, and the hundreds of small SHPPs were stopped. One of them was suspended, the other part is removed, and the remaining part is simply destroyed. As a result, today only 48 units SHPP remained in Ukraine (Fig. 28), most of which require the reconstruction [30]. These include a relatively powerful station as Tereble-Rikskaya, Gaivoronskaya, Korsun-Shevchenko, Steblevskaya, Ladizhinskaya and others.

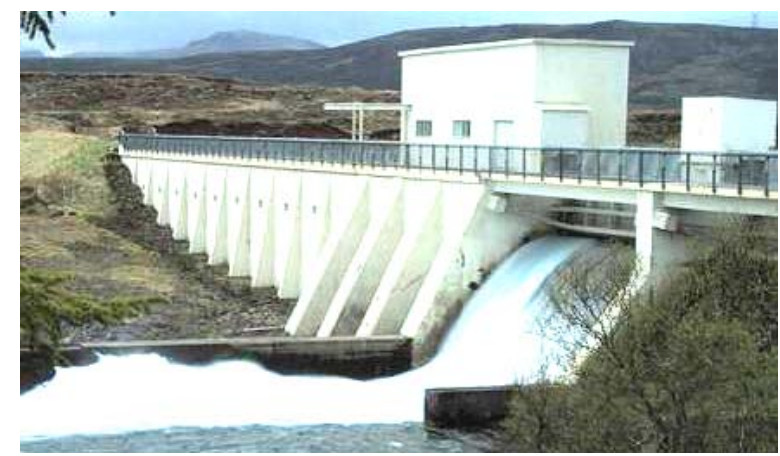

Fig. 28. General view of the dam and engine room of the domestic SHPP (2009, Ukraine) [30]
Of course, small hydropower of Ukraine because of its small specific weight (up to $0.2 \%$ [30]) in the total energy balance of the country may not significantly affect the conditions of its energy supply. However, exploitation of SHPP now makes it possible to produce about 250 million. $\mathrm{KW} \cdot \mathrm{h}$ of electricity per year. This is equivalent to annual savings of up to 75 thousand tons of scarce fossil fuels [8].

Conclusion. Alternative energy, despite its small share (up to $10 \%$ ) in the current total world annual balance of electricity generation due to the forced change in the next 50 years, oil and gas, «the foundation» of world energy on a large raw, potential and environmental capacity is large prospects for the development and use by the society.

\section{REFERENCES}

1. Available at: http://alt-energetic.ucoz.ru/index/0-10 (accessed 11 July 2015). (Rus).

2. Available at: https://en.wikipedia.org/wiki/Wind power (accessed 25 October 2013).

3. Available at: https://en.wikipedia.org/wiki/Solar_energy (accessed 03 May 2014).

4. Available at: https://en.wikipedia.org/wiki/Geothermal_energy (accessed 08 June 2014).

5. Available at: http://www.agro-t.de/Bio/biogas.html (accessed 05 January 2014).

6. Available at: https://en.wikipedia.org/wiki/Tidal_power (accessed 17 May 2015).

7. Available at: https://en.wikipedia.org/wiki/ Hydrogen economy (accessed 20 February 2015).

8. Available at: https://en.wikipedia.org/wiki/Small hydro (accessed 20 March 2015).

9. Available at: http://altenergy.in.ua/category/vetryanayaenergiya (accessed 02 April 2015).

10. Available

http://www.molomo.ru/myth/wind_energy.html (accessed 10 June 2015). (Rus).

11. Available at: http://masterok.livejournal.com/220814.html (accessed 10 May 2015). (Rus).

12. Available at: http://www.avante.com.ua/rus/library/ lib_perspektiv_soln_energetiki.htm (accessed 28 September 2014). (Rus).

13. Kuz'michev V.E. Zakony i formuly fiziki [Laws and formulas of physics]. Kiev, Naukova Dumka Publ., 1989. 864 p. (Rus).

14. Alferov Z.I., Andreev V.M., Rumyantsev V.D. Solar photovoltaics: Trends and prospects. Semiconductors, 2004, vol.38, no.8, pp. 899-908. doi: 10.1134/1.1787110.

15. Available at: http://alteco.in.ua/technology/solar-energy (accessed 20 October 2014).

16. Bol'shoj illjustrirovannyj slovar' inostrannyh slov [Large illustrated dictionary of foreign words]. Moscow, Russkie slovari Publ., 2004. 957 p. (Rus).

17. Krasnok A.E., Maksymov I.S., Denisyuk A.I. Belov P.A., Miroshnichenko A.E., Simovskii C.R., Kivshar Yu.S. Optical Nanoantennas. Uspehi fizicheskih nauk - Successes of physical sciences, 2013, vol.183, no.6, pp. 561-589. doi: 10.3367/ufnr.0183.201306a.0561.

18. Available https://en.wikipedia org/wiki/Photovoltaic power station at: cessed 22 November 2014).

19. Khramov Yu.A. Istoriia fiziki [History of Physics]. Kiev, Feniks Publ., 2006. 1176 p. (Rus).

20. Available at: http://re.energybel.by/en/geothermal/ (accessed 09 April 2014). 
21. Baranov M.I. Izbrannye voprosy elektrofiziki. Tom 3: Teorija i praktika elektrofizicheskih zadach [Selected topics of Electrophysics. Vol. 3: Theory and practice of electrophysics tasks]. Kharkiv, Tochka Publ., 2014. 400 p. (Rus).

22. Available at: http://www.energyofnature.org/2387 (accessed 12 March 2013).

23. Berman E., Mavritskiy B.F. Geotermal'naja energija [Geothermal energy]. Moscow, Mir Publ., 1978. 416 p. (Rus).

24. Available at: http://alternativenergy.ru/energiya/553prilivnaya-elektro-stanciya-princip-foto.html (accessed 18 May 2014). (Rus).

25. Available at: http://energetika.in.ua/ru/books/book-5/part1/section-2/2-5 (accessed 27 November 2014). (Rus).

26. Available

http://federalbook.ru/files/TEK/Soderzhanie/Tom\%2010/V/Kov

alchuk.pdf (accessed 27 November 2014). (Rus).

27. Available at: http://www.o8ode.ru/article/energy/energy.htm (accessed 04 March 2012). (Rus).

How to cite this article:

Baranov M.I. An anthology of the distinguished achievements in science and technique. Part 32: Alternative energy: state and prospects of development. Electrical engineering \& electromechanics, 2016, no.3, pp. 3-16. doi: 10.20998/2074-272X.2016.3.01.
28. Legasov V.A. Atomno-vodorodnaja energetika i tehnologija [Atomic hydrogen energy and technology]. Moscow, Atomizdat Publ., 1978. 475 p. (Rus).

29. Available at: http://www.cleandex.ru/articles/2008/03/18/hydropower2 (accessed 18 March 2008). (Rus).

30. Available at: http://alterpower.com.ua/energy-water/41malaya-gidro-energetika-ukraini (accessed 07 May 2015). (Rus).

Received 26.10.2015

M.I. Baranov, Doctor of Technical Science, Chief Researcher, Scientific-\&-Research Planning-\&-Design Institute «Molniya» National Technical University «Kharkiv Polytechnic Institute», 47, Shevchenko Str., Kharkiv, 61013, Ukraine, phone +38 057 7076841, e-mail: eft@kpi.kharkov.ua 